\title{
Responses to Lerner A. and Matthias T. Comment on "Microbial Enzymes as Substitutes of Chemical Additives in Baking Wheat Flour-Part II: Combined Effects of Nine Enzymes on Dough Rheology [M.M. Bueno, R.C.S. Thys and R.C. Rodrigues (2016), Food and Bioprocess Technology, 9(9), 1598-1611]"
}

\author{
Rafael C. Rodrigues ${ }^{1}$
}

Dear Prof. Sun (Editor-in-chief), In response to the Letter to Editor "Are microbial enzymes used safe in the processed food industries?", about our work "Microbial Enzymes as Substitutes of Chemical Additives in Baking Wheat Flour-Part II: Combined Effects of Nine Enzymes on Dough Rheology", we wish to say that:

1) We believe that in thermally processed food, as in baking, enzymes do not remain active in the final product, because the utilized temperature will result in the denaturation of the protein and would likely result in the loss of enzymatic activity.
2) We also believe that further studies should be made to ensure that enzymes are completely safe for food industries.

3) The objective of our work was to demonstrate potential application of microbial enzymes in baking, and we do not recommend the application of enzymes if they are not safe to human health.

Yours sincerely,

Dr. Rafael Costa Rodrigues

Head of Biocatalysis Laboratory

17th August 2016.

The commentary article is available at 10.1007/s11947-016-1794-y

Rafael C. Rodrigues

rafaelcrodrigues@ufrgs.br; http://www.ufrgs.br/bbb

Biocatalysis and Enzyme Technology Laboratory, Federal University of Rio Grande do Sul, State Av. Bento Gonçalves, 9500, Campus Do Vale, Po Box 15090, ZC 91501-970 Porto Alegre, RS, Brazil 